RADAELLI, Samuel Mânica; MEDINA, Júlio Eduardo Damasceno. O controle judicial de constitucionalidade de emendas à Constituição. Revista Eletrônica Direito e Política, Programa de Pós-Graduação Stricto Sensu em Ciência Jurídica da UNIVALI, Itajaí, v.15, n.3, 30 quadrimestre de 2020. Disponível em: www.univali.br/direitoepolitica - ISSN 1980-7791

\title{
O CONTROLE JUDICIAL DE CONSTITUCIONALIDADE DE EMENDAS À CONSTITUIÇÃO
}

\author{
THE JUDICIAL CONTROL OF CONSTITUTIONALITY OF AMENDMENTS TO \\ THE CONSTITUTION
}

\author{
Samuel Mânica Radaelli ${ }^{1}$ \\ Júlio Eduardo Damasceno Medina²
}

\section{RESUMO}

Estudar a relação entre constitucionalismo e democracia, impressa na relação de tensão entre o Supremo Tribunal Federal e o Congresso Nacional brasileiro é o objetivo do presente artigo. Para tanto dissertar-se-á acerca do controle judicial de constitucionalidade de Emendas à Constituição, bem como sobre a possibilidade de tal revisão judicial representar uma atrofia à soberania popular, ao passo que sucumbe a democracia ao julgamento final da interpretação constitucional por parte de uma corte não eleita e sem a possibilidade de ser responsabilizada politicamente por suas decisões. Não obstante, tal trabalho considera que a sindicabilidade judicial das Emendas à Constituição, sob o pretexto de proteção das cláusulas pétreas, representa em si a determinação de quem terá a última palavra sobre a interpretação da Constituição. A metodologia de pesquisa utilizou primordialmente a técnica de pesquisa bibliográfica e 0 método de abordagem é classificado como dialético.

PALAVRAS-ChAVE: Constitucionalismo; Democracia; Emendas Constitucionais.

\begin{abstract}
Studying the relationship between constitutionalism and democracy, imprinted in the tension relationship between the Federal Supreme Court and the Brazilian National Congress is the objective of this article. In order to do so, it will be discussed the judicial control of constitutionality of Amendments to the Constitution, as well as on the possibility of such judicial review representing an atrophy of popular sovereignty, while democracy succumbs to the final judgment of constitutional interpretation by a unelected court and without the possibility of being politically accountable for its decisions. Nevertheless, this work considers

\footnotetext{
1 Doutor em Direito pela Universidade Federal de Santa Catarina (UFSC) e Mestre em Direito Público pela Universidade do Val do Rio dos Sinos (UNISINOS). Professor Titular de Ciência Política, Filosofia e Sociologia do Direito do Instituto Federal do Paraná, portanto ligado ao IFPR - Campus Palmas, Paraná, Brasil. Titular e-mail: Samuel.radaelli@ifpr.edu.br.

${ }^{2}$ Bacharel em Direito pelo Instituto Federal do Paraná (IFPR) - Campus Palmas, portanto, ligado à instituição Instituto Federal do Paraná - Campus Palmas, Paraná, Brasil. Estudante, membro e fundador do Grupo de Pesquisas "Hermenêutica e Jurisdição Constitucional". Titular do e-mail: damascenomedina@mail.com.
} 
RADAELLI, Samuel Mânica; MEDINA, Júlio Eduardo Damasceno. O controle judicial de constitucionalidade de emendas à Constituição. Revista Eletrônica Direito e Política, Programa de Pós-Graduação Stricto Sensu em Ciência Jurídica da UNIVALI, Itajaí, v.15, n.3, 30 quadrimestre de 2020. Disponível em: www.univali.br/direitoepolitica - ISSN 1980-7791

that the judicial syndicability of the Amendments to the Constitution, under the pretext of protection of the stone clauses, represents in itself the determination of who will have the last word on the interpretation of the Constitution. The research methodology used primarily the bibliographic research technique and the approach method is classified as dialectical.

KEYWORDS: Constitutionalism; Democracy; Constitutional amendments.

\section{INTRODUÇÃO}

Não é recente o conflito entre o Supremo Tribunal Federal (Tribunal Constitucional Brasileiro ${ }^{3}$ ) e o Congresso Nacional Brasileiro. Podemos citar inúmeros exemplos como o afastamento de parlamentar do exercício do mandato de forma cautelar (ADI n. 5.526), a delimitação quantitativa de vereadores das Câmaras Legislativas dos Municípios (ADI n. 4.307), a proibição da vaquejada ${ }^{4}$ e a correspondência e observância obrigatória entre as coligações eleitorais em âmbito nacional, estadual, distrital e municipal (ADI n. 3.685).

Deste cabo de guerra surgem problemas tanto substanciais como procedimentais, ou melhor, problemas de hermenêutica constitucional e de arranjos institucionais. No que se refere aos arranjos institucionais, vários juristas defendem o Tribunal Constitucional como o melhor interprete da Constituição, enquanto outros contestam a existência e legitimidade democrática da Corte. Já no que se refere à hermenêutica constitucional as atenções deixam de lado as instituições e passam a analisar seus argumentos deliberativos, o que não deixa de perpetuar o conflito.

De toda sorte, os problemas não se limitam ao controle de constitucionalidade das leis. Em várias oportunidades o Parlamento superou a Corte ao aprovar uma Emenda à Constituição que fosse contrária ao atual entendimento judicial.

\footnotetext{
${ }^{3}$ Deve se atentar ao fato de que o Supremo Tribunal Federal não exerce somente a função de Tribunal Constitucional Brasileiro. O STF é, também, órgão de cúpula do Poder Judiciário. Não obstante atua como foro especializado e teve suas competências amplamente alargadas pelas Emendas à Constituição n. $3 / 93$ e n. 45/05 e pelas leis n. 9.868/99 e 9.882/99. Vide: VIEIRA, Oscar Vilhena. Supremocracia. In: Revista Direito FGV. v. 04, N. ${ }^{\circ} 02$. São Paulo: Fundação Getúlio Vargas, 2008. p. 444.

${ }^{4}$ Podemos dizer que este caso foi provisoriamente vencido pelo Parlamento ao aprovar a E.C. $n$. 96/2017, como resposta ao julgamento que decidiu pela proibição da vaquejada na ADI n. 4.983, de toda sorte o Fórum Nacional de Proteção e Defesa do Animal ajuizou a ADI n. 5.728, que questiona a constitucionalidade referida Emenda.
} 
RADAELLI, Samuel Mânica; MEDINA, Júlio Eduardo Damasceno. O controle judicial de constitucionalidade de emendas à Constituição. Revista Eletrônica Direito e Política, Programa de Pós-Graduação Stricto Sensu em Ciência Jurídica da UNIVALI, Itajaí, v.15, n.3, 30 quadrimestre de 2020. Disponível em: www.univali.br/direitoepolitica - ISSN 1980-7791

Contudo, termos que o STF tem realizado controle de constitucionalidade sobre emendas à Constituição. A Corte afirma ter sua legitimidade para tanto prevista no artigo 102, inciso I, alínea "a", da Constituição Federal.

A trajetória do presente artigo parte de esclarecimentos conceituais referentes ao Poder Constituinte, originário e de reforma. Na sequência, volta-se à análise dos limites materiais ao poder de reforma da Constituição e se a própria previsão de cláusulas pétreas, juntamente com a designação de sua proteção por parte do controle judicial de constitucionalidade, representa um fenômeno de atrofia do governo democrático. Ao final será procedida com uma análise de casos julgados pelo Supremo Tribunal Federal, onde essa Corte julgou a constitucionalidade de Emenda à Constituição.

\section{O PODER CONSTITUINTE E A REFORMA DA CONSTITUIÇÃO}

\subsection{Notas sobre o poder constituinte originário}

O Poder Constituinte é o poder inicial, autônomo, ilimitado, incondicionado e permanente ${ }^{5}$, que funda uma ordem jurídico política ao criar $^{6}$ uma Constituição. Devido a essas características, pode-se afirmar que o Poder Constituinte estabelece uma relação para com os demais poderes que se explica pela analogia do criados frente à sua criação.

Nitidamente sob a influência da obra de Sieyès ${ }^{7}$, Bernardo Gonçalves Fernandes comenta a relação entre o Poder Constituinte e os Poderes Constituídos:

\footnotetext{
${ }^{5}$ FERNANDES, Bernardo Gonçalves. Curso de Direito Constitucional. 7a ed. Salvador: Editora Juspodivm, 2015. p. $124-125$.

${ }^{6} \mathrm{O}$ termo criar tem suas origens na matriz constitucional francesa. Canotilho nos ensina que o fenômeno revelar, dizer ou criar a Constituição dependerá da experiência constituinte nacional. Cito: "os ingleses compreendem o poder constituinte como um processo histórico de revelação da 'constituição de Inglaterra'; os americanos dizem num texto escrito, produzido por um poder constituinte 'the fundamental and Paramount law of the nation'; os franceses criam uma novar ordem jurídico-constitucional através da 'destruição' do antigo regime da 'construção do novo', traçando a arquitetura da nova 'cidade política' num texto escrito - a constituição. Revelar, dizer e criar uma constituição são os modos operandi das três experiências constituintes". CANOTILHO, José Joaquim Gomes. Direito constitucional e teoria da constituição. $7^{a}$ ed. Lisboa: Almedina, 2003. p. 68 - 69.

7 SIEYÈS, Emmanuel Joseph. A constituinte burguesa: o que é o terceiro estado?. Rio de Janeiro: Líber Juris, 1988.
} 
RADAELLI, Samuel Mânica; MEDINA, Júlio Eduardo Damasceno. O controle judicial de constitucionalidade de emendas à Constituição. Revista Eletrônica Direito e Política, Programa de Pós-Graduação Stricto Sensu em Ciência Jurídica da UNIVALI, Itajaí, v.15, n.3, 30 quadrimestre de 2020. Disponível em: www.univali.br/direitoepolitica - ISSN 1980-7791

O Poder Constituinte institui uma nova ordem, a Constituição, marcando nitidamente uma diferente entre o ato de criação de uma Constituição e os atos jurídicos subsequentes - subordinando esses atos à Constituição. Portanto, detentores e destinatários do poder teriam que respeitar o documento produzido (pactuado) pelos mesmos (pela nação, nos termos de Sieyès), pois ambos, como já dito, eram constituídos pelo Poder Constituinte e sua obra: a Constituição ${ }^{8}$.

José J. G. Canotilho define Poder Constituinte como "o poder constituinte entendido como soberania constituinte do povo, ou seja, o poder de o povo através de um acto constituinte criar uma lei superior juridicamente ordenadora da ordem política" ${ }^{\prime 9}$.

Trazendo à baila da doutrina constitucional brasileira, podemos conceituar poder constituinte originário como:

Uma prerrogativa extraordinária que ocorre em um momento extraordinário e que visa à desconstrução de uma ordem anterior e a constituição de uma nova ordem constitucional (um poder desconstrutivo/constitutivo ou de despositivação/positivação) ${ }^{10}$.

Com a mesma finalidade de conceituar poder constituinte Barroso afirmar que "trata-se do poder de elaborar e impor a vigência de uma Constituição. Situa-se ele na confluência entre o Direito e a Política, e sua legitimidade repousa na soberania popular"11.

Seguindo, temos que a legitimidade do poder constituinte se encontra na soberania popular, uma vez que, modernamente fora abandonada a consideração de que sua titularidade caberia à nação. Por outro lado, atualmente, concebe-se o povo como titular do poder constituinte.

Quando o constitucionalismo se encontra em harmonia e interdependência com a soberania popular temos que o exercício do poder constituinte é democrático,

\footnotetext{
${ }^{8}$ FERNANDES, Bernardo Gonçalves. Curso de Direito Constitucional. p. 117.

${ }^{9}$ CANOTILHO, José Joaquim Gomes. Direito constitucional e teoria da constituição. p. 74.

10 FERNANDES, Bernardo Gonçalves. Curso de Direito Constitucional. p. 121.

11 BARROSO, Luís Roberto. Curso de direito constitucional contemporâneo: os conceitos fundamentais e a construção do novo modelo. 4a ed. São Paulo: Editora Saraiva, 2013. p. 120.
} 
RADAELLI, Samuel Mânica; MEDINA, Júlio Eduardo Damasceno. O controle judicial de constitucionalidade de emendas à Constituição. Revista Eletrônica Direito e Política, Programa de Pós-Graduação Stricto Sensu em Ciência Jurídica da UNIVALI, Itajaí, v.15, n.3, 30 quadrimestre de 2020. Disponível em: www.univali.br/direitoepolitica - ISSN 1980-7791

isto é, que ele se manifestou por meio de um processo democrático direto ou representativo. Para o processo democrático direto é necessário que seja realizada uma eleição para escolha dos representantes populares que formarão a Assembleia Constituinte e outro processo de chancela popular, podendo este ser por plebiscito ou referendo. De toda sorte, aos processos democráticos representativos só é necessário que haja uma eleição livre para escolha dos representantes ${ }^{12}$.

Nesse sentido, veja-se a obra de Barroso:

A teoria democrática se fixou na concepção de que a soberania é do povo. A Constituição, como regra, é elaborada por um órgão cujos membros são eleitos especificamente para esse fim. Em alguns países, a assembleia age diretamente em nove do povo e a Constituição será produto de sua deliberação, como é o caso da tradição brasileira ${ }^{13}$.

Dada sua natureza revolucionária e fundacional, o poder constituinte é classificado como sendo inicial, autônomo, incondicionado, permanente, indivisível e "ilimitado".

O poder constituinte originário é inicial porque "ele inaugura uma nova ordem jurídica e política, rompendo com a anterior ${ }^{\prime 14}$. Na mesma linha de raciocínio ele é autônomo ou exclusivo pois é impossível que coexistam dois poderes constituintes e duas soberanias, consequentemente é impossível que exista duas constituições na mesma "comunidade estatal"15. Sua incondicionalidade justificase, pois, cabe a si mesmo "estabelecer a sua forma de manifestação, não devendo obediência a nenhum procedimento previamente definido ${ }^{16}$. Em relação à característica permanente, podemos dizer que se deve ao fato de que o Poder Constituinte não se exaure com a confecção da Constituição, que materialmente

\footnotetext{
12 FERNANDES, Bernardo Gonçalves. Curso de Direito Constitucional. p. 128.

13 BARROSO, Luís Roberto. Curso de direito constitucional contemporâneo: os conceitos fundamentais e a construção do novo modelo. p. 131.

${ }^{14}$ FERNANDES, Bernardo Gonçalves. Curso de Direito Constitucional. p. 123.

15 SARLET, Ingo Wolfgang; MARINONI, Luiz Guilherme; MITIDIERO, Daniel. Curso de Direito Constitucional. 6a ed. São Paulo: Saraiva, 2017. p. 104.

${ }^{16}$ SOUZA NETO, Cláudio Pereira de; SARMENTO, Daniel. Direito Constitucional - Teoria, história e métodos de trabalho. $2^{\mathrm{a}}$ ed. Belo Horizonte: Fórum, 2014. p. 258.
} 
RADAELLI, Samuel Mânica; MEDINA, Júlio Eduardo Damasceno. O controle judicial de constitucionalidade de emendas à Constituição. Revista Eletrônica Direito e Política, Programa de Pós-Graduação Stricto Sensu em Ciência Jurídica da UNIVALI, Itajaí, v.15, n.3, 30 quadrimestre de 2020. Disponível em: www.univali.br/direitoepolitica - ISSN 1980-7791

ainda continuará existindo, mesmo que em estado de latência ${ }^{17}$. Já a indivisibilidade é decorrente da soberania legitima o poder constituinte, uma vez que esta é una e indivisível "não podendo ser compartilhada, sob pena de deixar de ser soberania"18.

Por outro lado, para tratar da característica "ilimitado" é necessário ter uma grande porção de cautela. Modernamente, o constitucionalismo e os constitucionalistas praticamente abandonaram a concepção positivista de que seria ilimitado. Luís Roberto Barroso advoga que o exercício do poder constituinte não se separa da realidade fática e nem do direito e que os valores civilizatórios (pós-positivistas, como diria) da justiça e dos direitos humanos impõe limites ao poder constituinte ${ }^{19}$.

Bernardo Gonçalves Fernandes é outro constitucionalista que defende a tese da limitação do poder constituinte. Segundo o constitucionalista da UFMG, as limitações são de ordem (i) territorial, uma vez que tal poder só vincula o território daquele Estado; (ii) cultural, considerando que as tradições e a cultura compartilhada pela sociedade não serão esquecidas no momento de elaborar a Constituição e; (iii) de direito humanos, haja visto que tais direitos são suprapositivos e oponíveis à deliberação majoritária ${ }^{20}$.

\subsection{A reforma da Constituição}

Passado o estudo inicial sobre o poder constituinte originário cumpre indagar seu papel revolucionário, uma vez que o mesmo é causa de um fator crítico para a sociedade: a instabilidade. Estaríamos fadados à obrigação de fundar uma nova constituição a cada vez que as preferências e necessidades sociais mudassem?

A resposta é negativa. Obviamente é mais prudente estabelecer mecanismos de reforma à constituição para não ficarmos reféns da revolução. O poder de

\footnotetext{
17 FERNANDES, Bernardo Gonçalves. Curso de Direito Constitucional. p. 124.

18 SOUZA NETO, Cláudio Pereira de; SARMENTO, Daniel. Direito Constitucional - Teoria, história e métodos de trabalho. p. 260.

19 BARROSO, Luís Roberto. Curso de direito constitucional contemporâneo: os conceitos fundamentais e a construção do novo modelo. p. 133.

${ }^{20}$ FERNANDES, Bernardo Gonçalves. Curso de Direito Constitucional. p. 124 - 125.
} 
RADAELLI, Samuel Mânica; MEDINA, Júlio Eduardo Damasceno. O controle judicial de constitucionalidade de emendas à Constituição. Revista Eletrônica Direito e Política, Programa de Pós-Graduação Stricto Sensu em Ciência Jurídica da UNIVALI, Itajaí, v.15, n.3, 30 quadrimestre de 2020. Disponível em: www.univali.br/direitoepolitica - ISSN 1980-7791

reformar a Constituição é chamado de Poder Constituinte Derivado. Tal instituto tem como principal atribuição "o poder de revisão constitucional a quem compete alterar, nos termos da constituição, as normas e princípios por esta fixadas" ${ }^{21}$.

Para justificar a necessidade de mecanismos de reforma, Barroso ensina que:

As Constituições não podem ser imutáveis. Os documentos constitucionais precisam ser dotados da capacidade de se adaptarem à evolução histórica, às mudanças da realidade e às novas demandas sociais. Quando não seja possível proceder a essa atualização pelos mecanismos informais descritos acima, será imperativa a modificação do texto constitucional. Se perder a sintonia com seu tempo, a Constituição já não poderá cumprir a sua função normativa e, fatalmente, cederá caminho para os fatores reais de poder $^{22}$.

$\mathrm{Na}$ democracia constitucional brasileira a reforma ou emenda à Constituição segue um procedimento diferenciado e mais custoso do que o utilizado para reformar a legislação infraconstitucional. A saber, o artigo 60, da Constituição Federal de 1988, estabelece parâmetros de competência para iniciativa de proposta de Emenda à Constituição ${ }^{23}$, outros limites procedimentais $^{24}$, limites circunstancias ${ }^{25}$ e, inclusive, limites de ordem material ou substancial ${ }^{26}$. Segundo Barroso são esse procedimento especifico, responsável

${ }^{21}$ CANOTILHO, José Joaquim Gomes. Direito constitucional e teoria da constituição. p. 68 69.

22 BARROSO, Luís Roberto. Curso de direito constitucional contemporâneo: os conceitos fundamentais e a construção do novo modelo. p. 162 - 163.

23 O artigo 60, caput, da Constituição, determina que: "A Constituição poderá ser emendada mediante proposta: I - de um terço, no mínimo, dos membros da Câmara dos Deputados ou do Senado Federal; II - do Presidente da República; III - de mais de metade das Assembleias Legislativas das Unidades da Federação, manifestando-se, cada uma delas, pela maioria relativa de seus membros.

24 Vários são os limites procedimentais que não aqueles de iniciativa, todos previstos no artigo 60, da $\mathrm{CF} / 88$. Estão inscritos no $\S 2{ }^{\circ}$, aqueles relativos à exigência de aprovação da proposta de emenda em dois turnos, de cada casa do Congresso nacional, considerando que cada aprovação deve obedecer ao quórum de três quintos dos votos, no $3^{\circ}$, relativo às exigências para promulgação e no $\S 50$, que veda a apreciação de proposta de emenda cuja matéria haja sido rejeitada naquela mesma sessão legislativa.

25 Quando se fala em limites circunstanciais se quer dizer que a Constiuição não pode ser emendada durante períodos de desequilíbrio social. A Constituição brasileira não pode ser reformada na vigência de intervenção federal, de estado de sitio ou de estado de defesa, por força da opção institucional do $\S 1^{\circ}$, do artigo 60, da CF/88.

${ }^{26}$ Os limites materiais de reforma à Constituição serão o objeto de estudo do item seguinte, em função disso, cumpre assinalar somente que estão previstos no §40, do artigo 60, da CF/88. 
RADAELLI, Samuel Mânica; MEDINA, Júlio Eduardo Damasceno. O controle judicial de constitucionalidade de emendas à Constituição. Revista Eletrônica Direito e Política, Programa de Pós-Graduação Stricto Sensu em Ciência Jurídica da UNIVALI, Itajaí, v.15, n.3, 30 quadrimestre de 2020. Disponível em: www.univali.br/direitoepolitica - ISSN 1980-7791

pela rigidez constitucional, juntamente com a previsão de emenda à constituição, os garantidores do equilibro entre estabilidade e adaptabilidade, tão buscado pelo constitucionalismo moderno ${ }^{27}$.

Bem lembram Daniel Sarmento e Claudio Pereira de Souza Neto que a Constituição de 1988 estabeleceu três mecanismos distintos para reforma da Constituição $^{28}$. De toda sorte, os comentários supracitados acerca de das previstos do artigo 60 da CF/88, relativos às Emendas à Constituição, também se aplicam à incorporação de tratados e convenções internacionais de direitos humanos, por expressa previsão do artigo 50, $3^{\circ}$, da Constituição. O terceiro mecanismo de reforma da Constituição é a dita revisão constitucional. A revisão constitucional está prevista no artigo 30, do ADCT, da Constituição, e nada mais é que "a designação de reformas extensas e profundas da Constituição"29. A revisão da Constituição de 1988 foi realizada durante o período de 01 de março de 1994 e 07 de junho de 1994, resultando na aprovação de 6 emendas de revisão ${ }^{30}$.

O fenômeno de garantir um processo próprio de reforma da Constituição, que seja diferente daquele utilizado para a legislação ordinária configura a opção constitucional de rigidez constitucional. A partir disso, a reforma da constituição é um evento que pode ser chamado de "momento constitucional", o qual diferencia as decisões frequentes do governo, das decisões raras, onde a soberania popular exige uma participação flagrante do povo na sua tomada.

Por outra banda, acreditam alguns constitucionalistas que há uma grande hierarquia entre o Poder Constituinte originário e o Poder Constituinte Derivado ou de reforma. Alguns afirmam que, propriamente, somente o Poder Constituinte originário é precipuamente constituinte e que os demais são constituídos:

\footnotetext{
27 BARROSO, Luís Roberto. Curso de direito constitucional contemporâneo: os conceitos fundamentais e a construção do novo modelo. p. 164.

${ }^{28}$ SOUZA NETO, Cláudio Pereira de; SARMENTO, Daniel. Direito Constitucional - Teoria, história e métodos de trabalho. p. 281.

29 BARROSO, Luís Roberto. Curso de direito constitucional contemporâneo: os conceitos fundamentais e a construção do novo modelo. p. 168.
}

${ }^{30}$ FERNANDES, Bernardo Gonçalves. Curso de Direito Constitucional. p. 136. 
RADAELLI, Samuel Mânica; MEDINA, Júlio Eduardo Damasceno. O controle judicial de constitucionalidade de emendas à Constituição. Revista Eletrônica Direito e Política, Programa de Pós-Graduação Stricto Sensu em Ciência Jurídica da UNIVALI, Itajaí, v.15, n.3, 30 quadrimestre de 2020. Disponível em: www.univali.br/direitoepolitica - ISSN 1980-7791

A rigor, só é propriamente constituinte o poder de criar a Constituição. É o chamado poder constituinte originário. Os demais, acima mencionados, são, na verdade, poderes constituídos, eis que instituídos e limitados pelo constituinte ${ }^{31}$.

No mesmo sentido, Rodrigo Brandão situa o Poder Constituinte de Reforma em um degrau abaixo do Poder Constituinte Originário e um degrau acima do Poder Legislativo ordinário:

A partir de uma perspectiva 'constitucionalista', pode-se vislumbrar o poder constituinte derivado como uma faculdade normativa que se situa em um ponto intermediário entre o poder legiferante ordinário. Com efeito, o poder de reforma da Constituição, ao gerar normas constitucionais, consubstancia-se em uma prerrogativa extraordinária - uma 'competência de competências'. Não se deve confundi-lo, todavia, com o poder soberano, pois, apesar de exorbitar o poder legislativo ordinário, busca fundamento de validade Constituição ${ }^{32}$.

Luís Roberto Barroso também é enfático em diferenciar o grau de importância constitucional entre o Poder Constituinte originário e o derivado. Para ele, mesmo se tratando, em ambos os casos, de "momentos constitucionais", ambos irão se diferenciar pela importância história e política das decisões, bem como pela desigual mobilização popular gerada na confecção da Constituição. Note-se:

Há momentos constitucionais nos quais o povo, a cidadania, impulsiona de maneira transformadora o processo social. Institucionalizada a nova ordem, o poder constituinte cede o passo ao poder constituído, o povo dá a vez a seus representantes. Esse aspecto envolvendo a participação cívica constitui um elemento diferenciador fundamental porque, via de regra, os membros da assembleia constituinte e aqueles que vêm a integrar o Parlamento acabam sendo substancialmente os mesmos. Mas as condições históricas e políticas de sua atuação, em razão do grau de mobilização popular, são muito diferentes ${ }^{33}$.

\footnotetext{
31 SOUZA NETO, Cláudio Pereira de; SARMENTO, Daniel. Direito Constitucional - Teoria, história e métodos de trabalho. p. 243.

32 BRANDÃO, Rodrigo. Direitos fundamentais, cláusulas pétreas e democracia. Rio de Janeiro: Renovar, 2008. p. 27 - 28.

33 BARROSO, Luís Roberto. Curso de direito constitucional contemporâneo: os conceitos fundamentais e a construção do novo modelo. p. 166.
} 
RADAELLI, Samuel Mânica; MEDINA, Júlio Eduardo Damasceno. O controle judicial de constitucionalidade de emendas à Constituição. Revista Eletrônica Direito e Política, Programa de Pós-Graduação Stricto Sensu em Ciência Jurídica da UNIVALI, Itajaí, v.15, n.3, 30 quadrimestre de 2020. Disponível em: www.univali.br/direitoepolitica - ISSN 1980-7791

Perpassada essa análise do poder constituinte derivado, podemos concluir, mesmo que sumariamente, que o poder reformador é visto como um poder de direito e inferior ao poder soberano do poder constituinte originário ${ }^{34}$. Estabelecese, pois, a relação já citada entre criador e sua criatura. No item que segue, o estudo centraliza-se nos limites materiais ao poder de reforma, as chamadas cláusulas pétreas e eventuais questionamentos de ordem democrático feitos em face de sua restrição ao autogoverno das gerações que seguem a geração constituinte, isto é, doravante questionar-se-á se a instituição de cláusulas pétreas e seu "entrincheiramento" pelo controle judicial de constitucionalidade representa ou não uma contenção da soberania popular.

\section{LIMITES MATERIAIS À REFORMA DA CONSTITUIÇÃO: AS CLÁUSULAS PÉTREAS E SUA TENSÃO COM A DEMOCRACIA}

O texto constitucional de 1988, prevê no $\S 4^{\circ}$ do artigo 60 que as propostas de emenda à Constituição não poderão ter como objeto a abolição (I) da forma federativa do Estado, (II) do voto direto, secreto, universal e periódico, (III) da separação dos Poderes e nem (IV) dos direitos e garantias individuais.

Essas vedações substanciais ao poder constituinte de reforma são chamados de limites materiais explícitos ou cláusulas pétreas. Tais limites devem servir como mecanismo para agir na ordem constitucional "na sua preservação, uma Constituição deverá conservar a essência de sua identidade original, o núcleo das decisões políticas e valores fundamentais que justificam a sua criação"35.

Contemporaneamente, parece plenamente aceitável que, para realização de tal guarda das cláusulas pétreas, seja necessário que se declare a inconstitucionalidade das eventuais Emendas à Constituição que sejam atentatórias aos limites materiais explícitos, sob pena de reduzir tais opções

\footnotetext{
34 BARROSO, Luís Roberto. Curso de direito constitucional contemporâneo: os conceitos fundamentais e a construção do novo modelo. p. 171.

35 BARROSO, Luís Roberto. Curso de direito constitucional contemporâneo: os conceitos fundamentais e a construção do novo modelo. p. 182.
} 
RADAELLI, Samuel Mânica; MEDINA, Júlio Eduardo Damasceno. O controle judicial de constitucionalidade de emendas à Constituição. Revista Eletrônica Direito e Política, Programa de Pós-Graduação Stricto Sensu em Ciência Jurídica da UNIVALI, Itajaí, v.15, n.3, 30 quadrimestre de 2020. Disponível em: www.univali.br/direitoepolitica - ISSN 1980-7791

constituintes "a uma mera discussão doutrinária, mais pertinente à metafisica política do que à teoria do Estado Constitucional" ${ }^{36}$.

Os casos emblemáticos em que STF firmou sua jurisprudência acerca do tema, serão objetos do próximo item desse capítulo (4.3). Contudo, não é cedo para afirmar que os dois alicerces argumentativos da Cortes tem sido, desde o julgado da ADI no 939-DF, (1) a supremacia da vontade do Poder Constituinte originário, devido ao fato de o mesmo ser titularizado pela soberania, em face da vontade do Poder Constituinte de Reforma, uma vez que este é mero poder constituído representativo, e não soberano, além de que (2) a Constituição determinou em seu artigo 102, caput, que cabe a incumbência precípua do STF é realizar a guarda da Constituição, seguindo pela opção de determinar a competência do mesmo para (inciso I, do artigo 102) "julgar e processar originariamente" (alínea "a") " a ação direta de inconstitucionalidade de lei ou ato normativo federal ou estadual e a ação declaratória de constitucionalidade de lei ou ato normativo federal" ${ }^{37}$.

Em face de tais argumentos e do próprio instituto do controle judicial de constitucionalidade de Emendas à Constituição. Em um primeiro momento, surgem questionamentos acerca da própria existência de limites materiais ao poder de reforma, materializados na crítica de que tal instituto promoveria um governo dos "mortos sobre os vivos", isto é, uma supremacia da vontade das gerações passadas sobre as gerações presentes e as futuras. Em segundo lugar, mas não menos importante, a crítica se direciona para a atribuição da fiscalização da constitucionalidade de Emendas à Constituição a cargo do poder judiciário, por gerar uma atrofia dos preceitos da democracia.

Aqueles que acreditam que as cláusulas pétreas e sua proteção judicial estariam em sentido contrário à antiga noção de soberania popular contida no artigo 28 da Declaração dos Direitos do Homem e do Cidadão, datada de 1793. Tal artigo, expressamente prevê que "um povo tem o direito de rever, de reformar e de mudar a sua constituição. Uma geração não poder sujeitar às suas leis as

36 BRANDÃO, Rodrigo. Direitos fundamentais, cláusulas pétreas e democracia. p. 44 apud VEGA, PEDRO. La Reforma Constitucional y La Problematica del Poder Constituyente. $5^{a}$ reimpresión. Madrid: Tecnos, 2000. p. 296.

${ }^{37}$ BRANDÃO, Rodrigo. Direitos fundamentais, cláusulas pétreas e democracia. p. 55 - 56. 
RADAELLI, Samuel Mânica; MEDINA, Júlio Eduardo Damasceno. O controle judicial de constitucionalidade de emendas à Constituição. Revista Eletrônica Direito e Política, Programa de Pós-Graduação Stricto Sensu em Ciência Jurídica da UNIVALI, Itajaí, v.15, n.3, 30 quadrimestre de 2020. Disponível em: www.univali.br/direitoepolitica - ISSN 1980-7791

gerações futuras". No mesmo sentido, e baseado na questão da igualdade moral da vontade de cada cidadão, o artigo 29 da mesma Declaração Universal prevê que "cada cidadão tem o direito igual de concorrer à formação da lei e à nomeação de seus mandatários e de seus agentes" ${ }^{\prime 38}$.

Com a fundamentação alicerçada em tais ideais, defensores da ilegitimidade democrática dos limites materiais ao poder de reforma da Constituição, terão basicamente quatro argumentos a seu favor. Rodrigo Brandão sintetiza tais considerações, expondo tais argumentos como: 10) é errado considerar que há diferenças entre o poder constituinte originário e o poder constituinte de reforma, uma vez que ambos materializam a vontade do povo e são expressões da soberania popular; $2^{\circ}$ ) se as normas constitucionais originárias e as derivadas estão inseridas na mesma ordem normativa e tem equivalência de eficácia jurídica e hierarquia normativa, será errado considerar que há distinção entre ambas; $3^{\circ}$ ) que efetivamente os limites materiais não poderão dar conta de restringir a vontade popular, servindo somente em tempos de normalidade e sendo ignorados em épocas de crise; e $4^{\circ}$ ) que a sua limitação ao poder constituinte de reforma levaria à organização revolucionária à invocação do poder constituinte originário e à criação de nova ordem constitucional, incentivando, assim, a instabilidade e fomentando eventual ruptura institucional ${ }^{39}$.

Por outro lado, levantam-se argumentos favoráveis às cláusulas pétreas, se baseando na competência do poder judiciário para declarar a inconstitucionalidade de norma que atente contra os valores e princípios basilares da democracia constitucional e na própria previsão estabilizadora do poder constituinte de reforma ${ }^{40}$.

Note-se que os argumentos reiteradamente utilizados para justificar a revisão judicial são: (i) o controle de constitucionalidade se apresenta como garantidora das pré-condições da democracia, ou (ii) de que o controle de constitucionalidade

\footnotetext{
38 A Declaração, em seu inteiro teor, se encontra disponível em: http://www.dhnet.org.br/direitos/anthist/dec1793.htm. Acesso em 23/05/2018 às 110h34min.

${ }^{39}$ BRANDÃO, Rodrigo. Direitos fundamentais, cláusulas pétreas e democracia. p. 21.

${ }^{40}$ BRANDÃO, Rodrigo. Direitos fundamentais, cláusulas pétreas e democracia. p. 23.
} 
RADAELLI, Samuel Mânica; MEDINA, Júlio Eduardo Damasceno. O controle judicial de constitucionalidade de emendas à Constituição. Revista Eletrônica Direito e Política, Programa de Pós-Graduação Stricto Sensu em Ciência Jurídica da UNIVALI, Itajaí, v.15, n.3, 30 quadrimestre de 2020. Disponível em: www.univali.br/direitoepolitica - ISSN 1980-7791

é um instituto consagrado pela opção institucional do artigo 102, inc. I, "a", da $\mathrm{CF} / 88$, ou ainda (iii) que a história do parlamento demonstra que tal poder não é tal democrático ao ponto de afastar o exercício da revisão judicial por ilegitimidade democrática, e que (iv) o controle de constitucionalidade pode servir como um veto a favor do poder judiciário para frear atitudes inconstitucionais das maiorias tirânicas, bem como instrumento propulsor de uma relação dinâmica entre os poderes.

No contexto brasileiro, principalmente em decorrência da ditadura militar iniciada com o golpe de 1964 e sua decorrente devastação de direitos fundamentais individuais e políticos, o primeiro argumento, que afirma a legitimidade da jurisdição constitucional a partir da proteção garantidas às pré-condições da democracia (dentre elas essencialmente estão os direitos fundamentais), parece guardar maior correspondência com a positivação superconstitucional postulada pela Constituição democrática de 1988. Assim entende Rodrigo Brandão:

A Constituição de 1988, como era de se esperar de uma Carta que, após uma longa vaga de autoritarismo, assumiu o status de marco jurídico do processo de redemocratização do país, incorporou o mais amplo rol de direitos e garantias fundamentais já previsto em constituições nacionais, trazendo-o, simbolicamente, para o início de seu texto. Para além disso, inseriu os 'direitos e garantias individuais' no elenco dos limites materiais ao poder de reforma, ao lado da forma federativa do Estado, do voto direto, universal e periódico e da separação dos Poderes (art. 60, parágrafo 4). ${ }^{41}$

Em termos dworkianos, o único inciso do $\S 4^{\circ}$, do artigo 60, da 60, que seria uma regra, isto é, seria aplicável utilizando 0 método tudo ou nada ${ }^{42}$. Consequentemente são normas jurídicas com grau de abstração e generalidade menor. Por outro lado, os demais incisos são princípios - "uma exigência de justiça ou equidade ou alguma outra dimensão da moralidade"43 -, normas jurídicas carregadas de abstração e generalidade, conceitos totalmente subjetivos.

\footnotetext{
${ }^{41}$ BRANDÃO, Rodrigo. Direitos fundamentais, cláusulas pétreas e democracia. p. 40.

42 DWORKIN, Ronald. Levando os Direitos a Sério. Tradução: Nelson Boeira. 3a. ed. São Paulo: Editora WMF Martins Fontes, 2010. p. 39.
}

${ }^{43}$ DWORKIN, Ronald. Levando os Direitos a Sério. p. 26. 
RADAELLI, Samuel Mânica; MEDINA, Júlio Eduardo Damasceno. O controle judicial de constitucionalidade de emendas à Constituição. Revista Eletrônica Direito e Política, Programa de Pós-Graduação Stricto Sensu em Ciência Jurídica da UNIVALI, Itajaí, v.15, n.3, 30 quadrimestre de 2020. Disponível em: www.univali.br/direitoepolitica - ISSN 1980-7791

Desta feita, a problemática de atribuir a proteção dos limites materiais ao poder de reforma surge por duas frentes, a primeira, procedimental, que questiona se tais conceitos subjetivos de princípios morais abstratos devem ser definidos pelo poder judiciário e a segunda, complementar da primeira, afirma que a soberania popular baseia-se no autogoverno coletivo e que a revisão judicial sobre normas constitucionais implica em desrespeito ao princípio democrático, tendo em vista que já que "federação", "separação dos poderes" e "direitos individuais" são conceitos que necessariamente terão juízos de interpretação moral divergente, não seria justo deixar sua significação a cargo de uma elite judicial não eleita. De toda forma, a intangibilidade das cláusulas pétreas por meio do Poder Judiciário parecia acertado, uma vez que garantiria que o núcleo constitucional não fosse abolido por uma maioria parlamentar ocasional.

Antes de se projetar a uma conclusão sobre o tema, devemos passar a análise de como o controle de constitucionalidade de emendas à Constituição têm afetado na prática a democracia constitucional brasileira, para tanto, deve ser feita uma releitura de alguns julgados do STF, à luz das moderações exigidas pelo princípio democrático.

\section{A INTERPRETAÇÃO DO SUPREMO TRIBUNAL FEDERAL}

Como o Supremo Tribunal Federal se comporta ante à análise da constitucionalidade de normas constitucionais? Ou melhor, tem, o STF, julgado inconstitucionais emendas à Constituição sob o argumento de que está a serviço da proteção das cláusulas pétreas? Ademais, esse posicionamento, em particular, tem sido desrespeitoso com os ideais constitucionais e democráticos? As novas gerações nacionais têm sofrido limitação de seu autogoverno por parte da revisão judicial?

Todas essas perguntas não tem uma resposta fácil, talvez, nem tenham uma resposta alcançável. De toda sorte, nas linhas que seguem este trabalho cuidou da análise de alguns dos julgados em que o STF afirmou sua posição, respondo aos dois primeiros questionamentos do parágrafo anterior. Às duas questões finais, serão apresentadas respostas, que mesmo insuficientes, 
RADAELLI, Samuel Mânica; MEDINA, Júlio Eduardo Damasceno. O controle judicial de constitucionalidade de emendas à Constituição. Revista Eletrônica Direito e Política, Programa de Pós-Graduação Stricto Sensu em Ciência Jurídica da UNIVALI, Itajaí, v.15, n.3, 30 quadrimestre de 2020. Disponível em: www.univali.br/direitoepolitica - ISSN 1980-7791

poderão ser encaradas como conclusão desse trabalho acerca do tema do controle de constitucionalidade de Emendas à Constituição.

Em março de 1996 o plenário do STF julgou a Ação Direta de Inconstitucionalidade n. 815, sob a relatoria do Ministro Moreira Alves. O requerente, Governador do Estado do Rio Grande do Sul, sustentava a tese de que há uma hierarquia entre normas constitucionais, estando as cláusulas pétreas degraus acima das demais no escalão constitucional. Em função disso, seria possível declarar a inconstitucionalidade de normas constitucionais, assim como já era concebido no direito alemão ${ }^{44}$.

No mérito, a ADI n. 815 questionava a constitucionalidade das redações dos §§ $1^{\circ}$ e $2^{\circ}$ do artigo 45 da Constituição, argumentando que o número mínimo de 8 deputados e máximo de 70 seria lesivo ao valor moral de cada voto individual, tendo em vista que Estados pequenos teriam uma representação maior do que o ideia e Estados gigantes populacionamente e econômica restariam subrepresentados. Em números da época, os Estados do Sul e Sudeste continham $57,2 \%$ da população e produziam o equivalente a $77,4 \%$ do PIB nacional e tinham direito a somente $45 \%$ das cadeiras do Congresso Nacional, enquanto os demais estados do Norte, Nordeste e Centro-Oeste tinham 42,3\% da população e $22,6 \%$ do PIB e povoavam o Congresso com $54,3 \%$ de suas vagas.

Tal ação, contudo, não foi conhecida pela impossibilidade jurídica do pedido, pela unanimidade dos Ministros do STF. A argumentação do Pretória Excelso baseouse na tese de que diante de um sistema constitucional rígido não há hierarquia entre normas constitucionais originárias. Para nosso tema em análise, importa que ficou decidido na ementa do acórdão que a guarda da constituição que compete ao supremo tribunal federal, por força do artigo 102, caput, não se confunde com um poder para fiscalizar o Constituinte originário, rechaçando a

\footnotetext{
${ }^{44}$ Rodrigo Brandão, nos ensina que "O Tribunal Constitucional Alemão (Bunderverfassungsgericht), embora também nunca haja declarada a inconstitucionalidade de emenda constitucional, afirmou, textualmente, a sua competência para fazê-lo (...) Embora transcenda o objeto do trabalho, convém pontuar que, se o Tribunal Constitucional Alemão já afirmara a sua competência para controlar a constitucionalidade de normas constitucionais originárias (fruto do poder constituinte originário), com muito mais razão pode fiscalizar a constitucionalidade de normas constitucionais derivadas. BRANDÃO, Rodrigo. Direitos fundamentais, cláusulas pétreas e democracia. p. 48 e 51 .
} 
RADAELLI, Samuel Mânica; MEDINA, Júlio Eduardo Damasceno. O controle judicial de constitucionalidade de emendas à Constituição. Revista Eletrônica Direito e Política, Programa de Pós-Graduação Stricto Sensu em Ciência Jurídica da UNIVALI, Itajaí, v.15, n.3, 30 quadrimestre de 2020. Disponível em: www.univali.br/direitoepolitica - ISSN 1980-7791

tese de que direitos supra positivos implicassem na invalidade de norma constitucional originária.

Ocorre que, mesmo antes desse julgamento, em 14 de abril de 1993, o STF apreciou a ADI n. 829, também sob a relatoria no Min. Moreira Alves, na qual decidiu, pela primeira vez, que o STF era competente para julgar a constitucionalidade de emendas constitucionais. Neste caso especifico a E.C. questionada era a n. 02/1992, que foi, de toda sorte, declarada constitucional e a Ação foi julgada improcedente. Tal decisão afastou a tese de impossibilidade jurídica do pedido, sob o argumento de que diante do novo sistema constitucional tal controle era uma incumbência da Corte.

Ainda em 1993, porém em dezembro, o STF voltou ao encontro do tema, quando na análise da ADI n. 939, nesta oportunidade, por sua vez, declarou a inconstitucionalidade de emenda constitucional, mais especificamente, no artigo 20, §20, da E.C. n. 03/1993. Para fundamentar o acordão conduzido pelo Min, Sydney Sanches, basearam-se no inc. IV, do $\S 40$ do artigo 60, da CF/88, considerando o princípio da anterioridade tributária como um direito individual.

Ao mesmo passo em que declarou a inconstitucionalidade de emenda constitucional, foi por meio da ADI 939, em que o Supremo se declarou guardião dos direitos individuais, mesmo que não expressos no rol do artigo 50, baseando-se na ampliação contida no $2^{\circ}$ do mesmo artigo 50, da CF/88.

O estudioso do tema Rodrigo Brandão, apesar de concordar com a decisão no tocante à proteção de direitos fundamentais por meio da declaração da inconstitucionalidade de emenda constitucional, critica-a, por considerar que a anterioridade tributária não é cláusula pétrea, restando assim, o julgamento do STF como excessivamente ampliativo de suas competências. Vejamos:

"Não há dúvidas de que a anterioridade tributária, ao proscrever a cobrança de tributos no mesmo exercício financeiro em que haja sido publicada a lei que os instituiu ou aumentou, consiste em instrumento de garantia, sob a forma de regra, do princípio da segurança jurídica. Isto porque se destina a garantir certeza jurídica em matéria tributária, permitindo que o contribuinte conheça o teor da lei impositiva no exercício financeiro anterior ao da cobrança, e, de conseguinte, possa fazer o planejamento 
RADAELLI, Samuel Mânica; MEDINA, Júlio Eduardo Damasceno. O controle judicial de constitucionalidade de emendas à Constituição. Revista Eletrônica Direito e Política, Programa de Pós-Graduação Stricto Sensu em Ciência Jurídica da UNIVALI, Itajaí, v.15, n.3, 30 quadrimestre de 2020. Disponível em: www.univali.br/direitoepolitica - ISSN 1980-7791

tributário da sua atividade. (...) a anterioridade tributária se encontra positivada fora do título II (afeto aos direitos e garantias fundamentais), de maneira que, não possuindo a natureza de direito formalmente fundamental, revela-se inequívoco não possuir de per se o status de cláusula pétrea. (...) consistindo, ao contrário, em instrumento destinado à satisfação de direito fundamental. Neste viés, a anterioridade não é uma prerrogativa que se justifica em si mesma, mas antes se consubstancia em regra destinada a promover a segurança jurídica ${ }^{45}$.

Percebe-se que ao tratar de "direitos fundamentais" para manusear seu argumento, Brandão se encontra em sintonia com a jurisprudência do STF, que passou a uma interpretação extensiva do aludido inc. IV, $\S 40$, do artigo 60, da $\mathrm{CF} / 88$, que possui como signo literal o termo "direitos individuais", ao status de cláusula pétrea. Tal entendimento fora adotado na ADI n. 1.946, a qual passamos a analisar.

Na ADI n. 1.946, também relatada pelo Min. Sydney Sanches e julgada em abril de 2003, o STF voltou a declarar a inconstitucionalidade de emenda constitucional, se apoiando na proteção de cláusulas pétreas. Por unanimidade o STF julgou parcialmente o pedido, para dar uma interpretação conforme a Constituição, sem redução do texto, ao artigo 14 da E.C. n. 20/1998, excluindo da sua aplicação ao salário da licença à gestante, garantido pelo artigo 70, inc. XVIII, da CF/88.

Note-se que em tal acordão o STF não se apegou à expressão exegética do inciso IV - direitos individuais - e acertadamente garantiu a proteção também aos direitos sociais, uma vez que todos são direitos fundamentais merecem a proteção supraconstitucional das cláusulas pétreas sem discriminação. De toda sorte, tal decisão também encontra amparo em direitos individuais, precipuamente aqueles previstos no artigo 50 , caput e inc. I, que garantem a igualdade entre homens e mulheres, uma vez que se o direito ao benefício previdenciário da licença à gestante fosse reduzido ao teto de $R \$ 1.200,00$, como queria o E.C. n. 20, estaria o STF convalidando uma causa de redução de direito social da mulher trabalhadora, cuja consequência seja o desrespeito pelo direito individual da igualdade, uma vez que o mercado de trabalho cuidaria de

${ }^{45}$ BRANDÃO, Rodrigo. Direitos fundamentais, cláusulas pétreas e democracia. p. 291 e 292. 
RADAELLI, Samuel Mânica; MEDINA, Júlio Eduardo Damasceno. O controle judicial de constitucionalidade de emendas à Constituição. Revista Eletrônica Direito e Política, Programa de Pós-Graduação Stricto Sensu em Ciência Jurídica da UNIVALI, Itajaí, v.15, n.3, 30 quadrimestre de 2020. Disponível em: www.univali.br/direitoepolitica - ISSN 1980-7791

discriminar a contratação ou promoção de mulheres trabalhadoras, em razão de ter que suportar com o salário, em caso de maternidade, daquelas mulheres cujos rendimentos superassem o teto de $\mathrm{R} \$ 1.200,00$.

Três anos mais tarde, em maio de 2006, o STF voltou a proferir mais uma decisão paradigmática acerca do aludido tema. Tal julgado foi numerado como Mandado de Segurança n. 24.875, no qual foi discutida a constitucionalidade da emenda constitucional n. 41/2003. O processo foi relatado pelo Min. Sepúlveda Pertence e mais uma vez passaram afirmar a possibilidade jurídica do pedido, nos seguintes termos:

\begin{abstract}
A viabilidade do controle da constitucionalidade formal ou material das emendas à Constituição - que se pode dar por assente do direito comparado -, é, no Brasil, diversamente de muitos países, prática incontroversa deste Tribunal desde a única reforma à Constituição da Primeira República, retomada sob a Carta de 1969 e, com mais frequência e diversas declarações de invalidade, sob o regime de 1998, vigente $^{46}$.
\end{abstract}

A discussão por trás de tal Mandado de Segurança ia além, uma vez que colocava diante do controle de constitucionalidade a seguinte questão: pode uma emenda à constituição ferir o direito adquirido? Isto é, o direito adquirido se apresenta como uma cláusula pétrea?

No caso em tela, argumentavam os impetrantes da segurança que a emenda constitucional n. 41, feriu seus direitos adquiridos de continuarem recebendo duas parcelas de cunho pessoal que integravam sua remuneração, quais seja, um adicional máximo de $35 \%$ por tempo de serviço e outro de $20 \%$, por terem se aposentado no exercício de cargo isolado no qual permaneceram por mais de três anos. Pois bem, nota-se que tal pedido foi contra o ideário constitucional de limitar toda e qualquer remuneração pública ao teto constitucional, servindo a Emenda como correção ao antigo posicionamento errôneo do STF. Ademais, o STF deferiu em parte o Mandado, por 6 votos a 5, para que os impetrantes continuassem a recebem tal vantagem, até que fosse absorvida pelos subsídios dos ministros do STF.

\footnotetext{
${ }^{46}$ Voto do Min. Rel. Sepúlveda Pertence, no MS n. 24.875, julgado pelo Tribunal Pleno do Supremo Tribunal Federal, em 11 de maio de 2006. p. 297.
} 
RADAELLI, Samuel Mânica; MEDINA, Júlio Eduardo Damasceno. O controle judicial de constitucionalidade de emendas à Constituição. Revista Eletrônica Direito e Política, Programa de Pós-Graduação Stricto Sensu em Ciência Jurídica da UNIVALI, Itajaí, v.15, n.3, 30 quadrimestre de 2020. Disponível em: www.univali.br/direitoepolitica - ISSN 1980-7791

Com posicionamento brilhantemente republicano, o constitucionalista Rodrigo Brandão questiona o julgado, se posicionando de maneira crítica ao julgado:

Ao nosso ver, a melhor exegese se encontra nos votos vencidos. Com efeito, ante a evidente inclusão das vantagens pessoais na expressão 'valores recebidos a qualquer título, parece-nos que o constituinte derivado apenas 'corrigiu' a jurisprudência do STF, que, nitidamente, havia se desviado da claríssima intenção do constituinte originário de submeter toda e qualquer remuneração percebida no serviço público ao teto remuneratório, procedendo, portanto, à interpretação autêntica do texto constitucional $^{47}$.

É necessário ressaltar que o relator Min. Sepúlveda Pertence advertiu que não é todo e qualquer direito adquirido que está apto a ser qualificado como limite material ao poder constituinte de reforma. No item $\mathrm{V}, 1$, da Ementa, o Ministro alegou que "aos impetrantes, porque magistrados, a Constituição assegurou diretamente o direito à irredutibilidade de vencimentos - modalidade qualificada de direito adquirido, oponível às emendas constitucionais mesmas" ${ }^{48}$.

Segundo a jurisprudência do Supremo, somente com a robusta demonstração de a lesão ao direito adquirido causará a atrofia de demais com status constitucional é que se invalida a emenda constitucional, sob pena de "à mingua de demonstração exauriente, neste sentido, impede ser declarada a inconstitucionalidade da respectiva emenda"49.

Outro princípio constitucional que serviu de marco para o controle de constitucionalidade de emendas à Constituição foi o princípio da anterioridade eleitoral, previsto no artigo 16 , da CF/88.

No primeiro caso que iremos analisar, a alegação de violação à anterioridade eleitoral configurava desrespeito a dois direitos fundamentais, segurança jurídica - art. 50, caput - e devido processo legal - artigo 50, LIV, e por isso a declaração de inconstitucionalidade se fundamentou, novamente, no $\S 4^{\circ}$, inc. IV,

\footnotetext{
47 BRANDÃO, Rodrigo. Direitos fundamentais, cláusulas pétreas e democracia. p. 328.

48 Ementa do Acórdão redigida pelo Min. Rel. Sepúlveda Pertence, no MS n. 24.875, julgado pelo Tribunal Pleno do Supremo Tribunal Federal, em 11 de maio de 2006. p. 286.
}

49 BRANDÃO, Rodrigo. Direitos fundamentais, cláusulas pétreas e democracia. p. 330. 
RADAELLI, Samuel Mânica; MEDINA, Júlio Eduardo Damasceno. O controle judicial de constitucionalidade de emendas à Constituição. Revista Eletrônica Direito e Política, Programa de Pós-Graduação Stricto Sensu em Ciência Jurídica da UNIVALI, Itajaí, v.15, n.3, 30 quadrimestre de 2020. Disponível em: www.univali.br/direitoepolitica - ISSN 1980-7791

do artigo 60, da CF/88. Trata-se da ADI n. 3.685 que impugnou a constitucionalidade da E.C. n. 52/2006.

A referida Emenda à Constituição n. 52/2006 entrou em vigor em 08 de março de 2006, com a seguinte redação:

Art. $1^{\circ} \bigcirc \S 10$ do art. 17 da Constituição Federal passa a vigorar com a seguinte redação:

Art.

$\S 1^{0}$ É assegurada aos partidos políticos autonomia para definir sua estrutura interna, organização e funcionamento e para adotar os critérios de escolha e o regime de suas coligações eleitorais, sem obrigatoriedade de vinculação entre as candidaturas em âmbito nacional, estadual, distrital ou municipal, devendo seus estatutos estabelecer normas de disciplina e fidelidade partidária.

Art. $2^{\circ}$ Esta Emenda Constitucional entra em vigor na data de sua publicação, aplicando-se às eleições que ocorrerão no ano de 2002.

Em razão de faltarem menos de 7 meses para as eleições de 2006, o Conselho Federal da OAB impugnou a referida emenda, alegando que sua inconstitucionalidade seria decorrente do desrespeito ao prazo de um ano entre a publicação da legislação eleitoral e a sua aplicabilidade em eleição exigido pelo artigo 16, da CF/88, isto é, não sendo aplicável em eleições às legislações cuja vigência seja inferior a um ano. O pedido foi julgado procedente, em 22 de março de 2006 e o $\S 2^{\circ}$ da E.C. n. 52 foi declarado inconstitucional, sob o fundamento de que o desrespeito à anterioridade eleitoral feriria a segurança jurídica e o devido processo legal.

De toda sorte, o caso é complexo, e exige que seja compreendido o conceito de "verticalização". A verticalização das coligações para eleição majoritária exige que se determinado partido coligou-se com outros determinados partidos para a eleição presidencial, então será vedado que celebre coligações com outros partidos - senão aqueles em coligou-se na eleição para Presidente da República - visando as eleições para Governador dos Estados. 
RADAELLI, Samuel Mânica; MEDINA, Júlio Eduardo Damasceno. O controle judicial de constitucionalidade de emendas à Constituição. Revista Eletrônica Direito e Política, Programa de Pós-Graduação Stricto Sensu em Ciência Jurídica da UNIVALI, Itajaí, v.15, n.3, 30 quadrimestre de 2020. Disponível em: www.univali.br/direitoepolitica - ISSN 1980-7791

Essa regra, "a verticalização", não foi adotada para a eleição de 04 de outubro 1998, tendo em vista que estava vigente o artigo 60, da Lei 9.504, o qual regra que:

É facultado aos partidos políticos, dentro da mesma circunscrição, celebrar coligações para eleição majoritária, proporcional, ou para ambas, podendo, neste último caso, formar-se mais de uma coligação para a eleição proporcional dentre os partidos que integram a coligação para o pleito majoritário.

Em 2002, acerca da matéria, e questionando a interpretação acerca da possibilidade ou não de verticalização, quatro Deputados Federais formularam a seguinte consulta ao Tribunal Superior Eleitoral:

Pode um denominado partido político (partido A) celebrar coligação, para eleição de Presidente da República, com alguns partidos (partido B, C, e D) e, ao mesmo tempo, celebrar coligação com terceiros partidos ( $E, F$ e $G$, que também possuem candidato à Presidência da República) visando à eleição de Governador de Estado da Federação.

O TSE respondeu negativamente à consulta, editando no dia 26 de fevereiro de 2002, a Resolução n. 21.002, cuja redação, que era imperativa obrigando a verticalização de coligações, foi aplicada nas eleições 06 de outubro de 2002, isto é, a menos de um ano de sua publicação.

Note-se que mesmo diante de flagrante desrespeito à anterioridade eleitoral, o STF não declarou a inconstitucionalidade da referida resolução, mesmo quando questionado na ADI n. 2.628, afirmando (i) a impossibilidade de exercer o controle abstrato de constitucionalidade de ato infra legal e (ii) que tal Resolução não demonstrava afronta a nenhum dispositivo Constitucional.

Veja-se que à época vigora a redação original do artigo $17, \S 1^{0}$, a qual na literalidade dizia que: "é assegurada aos partidos políticos autonomia para definir sua estrutura interna, organização e funcionamento, devendo seus estatutos estabelecer normas de fidelidade e disciplina partidárias". Ocorre que na própria votação no TSE, da Resolução n. 21.002, o Min. Sepúlveda Pertence advertiu que sua aprovação tinha viés autoritário e incompatível com a opção normativa da Constituição que garantia autonomia aos partidos políticos. Ademais, 
RADAELLI, Samuel Mânica; MEDINA, Júlio Eduardo Damasceno. O controle judicial de constitucionalidade de emendas à Constituição. Revista Eletrônica Direito e Política, Programa de Pós-Graduação Stricto Sensu em Ciência Jurídica da UNIVALI, Itajaí, v.15, n.3, 30 quadrimestre de 2020. Disponível em: www.univali.br/direitoepolitica - ISSN 1980-7791

argumentou que: "o 'pluralismo político' - que é um dos fundamentos da República - aborrece a unificação compulsória de um modelo de organização e decisão partidárias.

Claudio Pereira de Souza Neto também recebeu a aludida Resolução com observações críticas:

Se estruturaram as estratégias partidárias e foram tomadas importantes decisões políticas. A decisão do TSE surpreendeu a todos e agregou às eleições daquele ano uma forte dose de incerteza; representou, no mínimo, a substituição da uma interpretação (mais corrente e mais próxima do texto legal) por outra interpretação (mais construída e estranha ao texto), a menos de um ano da realização do certame eleitoral ${ }^{50}$.

Como resposta, o Parlamento, apresentou a Proposta de Emenda à Constituição n. 548, em 11 de junho de 2002, a qual somente foi aprovada, em sua maioria qualificada de três quintos, em 2006, como Emenda à Constituição n. 52.

Deve-se atentar ao fato de que duas normas (com hierarquias constitucionais diversas) atentaram ao princípio da anterioridade eleitoral e somente uma delas foi declarada inconstitucional, por atentar à segurança jurídica e ao devido processo legal. Seria porque a norma revogada teve aprovação 343 deputados e 60 senadores (em 10 turno) e 329 deputados e 57 senadores (em 20 turno) e a norma ratificada pelo STF teve a numerosa aprovação de 05 ministros não eleitos do TSE? Ou, talvez, seria porque uma for aprovada pelo Poder Judiciário e também julgada pelo Poder Judiciário e a outra pelo Congresso Nacional?

Com enorme preocupação democrática e republicana, Rodrigo Brandão apresenta uma crítica louvável, ponderada, no aspecto de balancear a legitimidade democrática do Congresso Nacional e do Poder Judiciário para a atividade legislativa:

Ora, se o conturbado contexto que se seguiu às eleições de 2002 não permitia prever, com um grau mínimo de certeza, qual seria a regra regente do processo eleitoral de 2006, não

\footnotetext{
50 SOUZA NETO, Cláudio Pereira. Verticalização, cláusula de barreira e pluralismo político: uma crítica consequencialista à decisão do STF na ADIn n. 3685-8. Disponível em: https://bdjur.stj.jus.br/jspui/handle/2011/30652. Acesso em: 02 jun. 2018, às 00h31min.
} 
RADAELLI, Samuel Mânica; MEDINA, Júlio Eduardo Damasceno. O controle judicial de constitucionalidade de emendas à Constituição. Revista Eletrônica Direito e Política, Programa de Pós-Graduação Stricto Sensu em Ciência Jurídica da UNIVALI, Itajaí, v.15, n.3, 30 quadrimestre de 2020. Disponível em: www.univali.br/direitoepolitica - ISSN 1980-7791

parece legítimo, à luz do princípio democrático, que o STF, com base, precisamente, no princípio da segurança jurídica, faça prevalecer a interpretação do TSE à lavrada pelo Congresso Nacional, já que, tanto a decisão do primeiro quanto a do último foram tomadas a menos de um ano das eleições de 2002 e 2006, respectivamente. Com efeito, inexistindo segurança jurídica a proteger, já que não havia elementos para se concluir com segurança qual seria a disciplina normativa da questão, não há que se falar em violação à cláusula pétrea, de modo que, ao nosso ver, a orientação fixada pela supermaioria dos membros do Congresso Nacional deveria ser reverenciada pelo Poder Judiciário. Cuida-se, a propósito, de corolário da tese desenvolvida o curso do trabalho, no sentido de interpretarse 0 art, 60, §40, IV, da CF/88, com razoável dose de autorestrição judicial, de maneira a preservar a intangibilidade dos ditos elementos constitucionais essenciais sem malferimento do princípio democrático ${ }^{51}$.

Conforme foi advertido nas linhas iniciais deste tópico, este é um dos riscos de deixar os limites materiais de reforma da Constituição sob a tutela do Poder Judiciário, tendo em vista que, atribui-se a este órgão, que não naturalmente democráticos, pois não é eleito e não presta contas aos cidadãos, uma palavra final na interpretação da Constituição, tendo em vista que depois da declaração da inconstitucionalidade de Emenda à Constituição não caberá ao Congresso Nacional a tomada de nenhuma decisão normativa formal, pois as normas constitucionais já ocupam a mais alta hierarquia do ordenamento jurídico brasileiro.

Outro exemplo que nos demonstra que o entendimento de que é cabível o controle judicial de constitucionalidade de emenda constitucional é o caso do julgado da chamada "emenda do calote", a E.C. n. 62/2009, impugnada pelas ADI's n. 4.357, n. 4.372, n. 4.400 e n. 4.425 .

Em tal julgamento a decisão do STF assentou-se na inconstitucionalidade do contemporâneo §12, do artigo 100, da CF/88, cuja redação havia sido modelada pela E.C. n. 62/2009, por decisão da maioria de seus membros. A título de fundamentação, novamente assentaram-se os ministros na violação de direitos fundamentais, neste caso, teriam sido a isonomia (art. 50, caput, CF/88), o

${ }^{51}$ BRANDÃO, Rodrigo. Direitos fundamentais, cláusulas pétreas e democracia. p. 301. 
RADAELLI, Samuel Mânica; MEDINA, Júlio Eduardo Damasceno. O controle judicial de constitucionalidade de emendas à Constituição. Revista Eletrônica Direito e Política, Programa de Pós-Graduação Stricto Sensu em Ciência Jurídica da UNIVALI, Itajaí, v.15, n.3, 30 quadrimestre de 2020. Disponível em: www.univali.br/direitoepolitica - ISSN 1980-7791

acesso à justiça (art. 50, XXXV, CF/88), o respeito à coisa julgada material e ao direito adquirido (art. 50, XXXVI, CF/88), além do desprezo ao direito à propriedade (art. 50, XXII, CF/88).

Nesta etapa do trabalho, podemos concluir que o controle de constitucionalidade de emendas tem sido utilizado de maneira exaustiva, tanto quanto a Constituição tem sido reformada de maneira exaustiva, tendo em vista que em outubro de 2018 comemoraremos os 30 anos de vigência da Constituição e, provavelmente, teremos superado o número de 100 (cem) emendas constitucionais, haja visto que em junho do corrente ano já foram promulgadas 99 (noventa e nove). São 310 meses, desde a promulgação da primeira emenda, e uma implacável média de uma reforma a cada 3 meses, até a Emenda à Constituição n. 99/2017.

Recentemente, cinco dentre as seis últimas emendas promulgadas, tiveram sua constitucionalidade questionada perante o STF perante o STF. Nenhum dos processos está encerrado ou teve julgamento pelo Plenário, mas a estatística de questionamento perante o STF revela que virou regra a judicialização do processo de reforma da Constituição. Ressalte-se que, nesses cinco casos recentes, a Procuradora Geral da República é autora de três Ações Diretas, demonstrando sua assiduidade na judicialização da política.

Somente a título de conhecimento, os casos citados tratam-se da ADI n. 5.679, que questionou a constitucionalidade da E.C. n. 94/2016; ADI n. 5.643, impugnando a E.C. n. 95/2016; ADI n. 5.875, que questiona a EC n. 97/2017; e, por fim a ADI 5935, que visa a declaração da integralidade da E.C. n. 98/2017.

Por fim, temos a ADI n. 5.728, que questionou a constitucionalidade E.C. n. 96/2017. Tal caso merece uma análise especial, dado à sua peculiaridade, pertinente à investigação desse trabalho. No mérito, tal caso consiste na discussão acerca da compatibilidade da pratica da "vaquejada" com a ordem constitucional vigente.

Em 06 de outubro de 2016 o STF julgou a ADI n. 4.983 procedente, por seis votos a cinco, e declarou inconstitucional a Lei n. 15.299, do Estado do Ceará. Tal legislação cuidava de regulamentar a vaquejada como pratica desportiva e cultural do referido estado e fui revogada em face da decisão do STF que 
RADAELLI, Samuel Mânica; MEDINA, Júlio Eduardo Damasceno. O controle judicial de constitucionalidade de emendas à Constituição. Revista Eletrônica Direito e Política, Programa de Pós-Graduação Stricto Sensu em Ciência Jurídica da UNIVALI, Itajaí, v.15, n.3, 30 quadrimestre de 2020. Disponível em: www.univali.br/direitoepolitica - ISSN 1980-7791

compreendeu tal prática como cruel e fomentadora de pensamentos onde os animais são "coisas" descartáveis.

Considerando que tal prática era uma tradição secular do nordeste brasileiro e que gera uma movimentação econômica considerável, o Parlamento desafio a consideração do STF, e editou a E.C. n. 96/2017 em total incompatibilidade com a consideração de intrínseca crueldade da vaquejada, eis que acrescentou o $\S 70$ ao artigo 225, da CF/88, cuja redação é:

Art. 225. $\S 70$ Para fins do disposto na parte final do inciso VII do $\S 1^{0}$ deste artigo, não se consideram cruéis as práticas desportivas que utilizem animais, desde que sejam manifestações culturais, conforme o $\S 1^{\circ}$ do art. 215 desta Constituição Federal, registradas como bem de natureza imaterial integrante do patrimônio cultural brasileiro, devendo ser regulamentadas por lei específica que assegure o bem-estar dos animais envolvidos.

A Ação Direta de Inconstitucionalidade n. 5.728 terá que enfrentar dois problemas, (i) um de direito material, acerca da constitucionalidade da vaquejada, passando necessariamente pela colisão entre direito ao desperto e à cultura contra o direito ao meio ambiente e ao objetivo fundamental da República de construir uma sociedade livre, justa e solidária, e, outro, (ii) que mais interessa à discussão aqui proposta, acerca do conflito entre a interpretação do STF e a do Congresso Nacional, na concretização da Constituição.

A título de palpite, provavelmente o STF seguirá sua jurisprudência sólida e superará a alegação de impossibilidade jurídica do pedido, pois acredita ser competente para realizar o controle de constitucionalidade de emenda constitucional. De toda sorte, resta claro que o Parlamento resolveu enfrentar a interpretação jurídica e editou uma emenda em tempo hábil, uma vez a proibição da vaquejada foi em outubro de 2016 e a emenda fora publicada em junho de 2017, o que, de per si, demonstra a mobilização legislativa em face de determinado objetivo. 
RADAELLI, Samuel Mânica; MEDINA, Júlio Eduardo Damasceno. O controle judicial de constitucionalidade de emendas à Constituição. Revista Eletrônica Direito e Política, Programa de Pós-Graduação Stricto Sensu em Ciência Jurídica da UNIVALI, Itajaí, v.15, n.3, 30 quadrimestre de 2020. Disponível em: www.univali.br/direitoepolitica - ISSN 1980-7791

\section{CONSIDERAÇÕES FINAIS}

Este tópico cuidará de uma sintética conclusão acerca do controle de constitucionalidade de Emendas à Constituição. Sem precipitar um juízo acerca do questionamento da legitimidade democrática do controle de constitucionalidade de leis, buscar-se-á responder se, confiar a fiscalização da constitucionalidade de emendas constitucionais gera uma limitação à soberania popular? Em caso afirmativo, se tal controle oferece benefícios compensatórios capazes de legitimar tal restrição.

O admirável constitucionalista paranaense, Paulo Ricardo Schier, preocupado com a proteção dos direitos fundamentais, aceita a existência de cláusulas pétreas, bem como a fiscalização judicial dos limites materiais ao poder de reforma. Vejamos que:

No sistema brasileiro, em vista de peculiaridades históricas antes referidas, é absolutamente compreensível e admissível a previsão de cláusulas pétreas. A tutela dos direitos fundamentais mediante o gravame da intangibilidade, na experiência constitucional de 1988, aparece mais como uma tentativa de afirmação e reforço da democracia do que como um desafio ao princípio democrático. Expressa, antes, uma certa e fundada desconfiança em relação aos poderes constituídos. Ademais, razões de ordem política, cultural e social têm justificado o reconhecimento da existência de uma crise de legitimidade do Poder Legislativo, que se expressa através da 'crise de representatividade ${ }^{52}$.

A citada "crise de representatividade" também é uma preocupação de Rodrigo Brandão. O estudioso, partindo do pressuposto de que o STF ocupa um papel relativamente restrito da atualização da Constituição, se comparado àquele da Suprema Corte dos Estados Unidos, também compactua com o controle judicial de constitucionalidade de emendas constitucionais ${ }^{53}$.

Não obstante, na esteira de Brandão, se o processo de reforma da constituição estiver intocável das decisões do Poder Judiciário corre-se dois riscos graves. 0 primeiro consiste na confusão entre soberania popular e representação, uma vez

\footnotetext{
52 SCHIER, Paulo Ricardo. Direitos fundamentais, cláusulas pétreas e democracia: campo de tensão. Revista Direitos Fundamentais e Democracia, v. 6, 2009. p. 7.

${ }^{53}$ BRANDÃO, Rodrigo. Direitos fundamentais, cláusulas pétreas e democracia. p. 174.
} 
RADAELLI, Samuel Mânica; MEDINA, Júlio Eduardo Damasceno. O controle judicial de constitucionalidade de emendas à Constituição. Revista Eletrônica Direito e Política, Programa de Pós-Graduação Stricto Sensu em Ciência Jurídica da UNIVALI, Itajaí, v.15, n.3, 30 quadrimestre de 2020. Disponível em: www.univali.br/direitoepolitica - ISSN 1980-7791

que, mesmo que o Congresso Nacional represente a vontade de toda população da federação, delegada em uma eleição democrática, não poderíamos confundir poder para legislar com soberania, uma vez que esta é somente do povo. Em segundo lugar, também estaríamos diante do risco de abandonar valores consagrados pelo constitucionalismo e pela democracia à mercê de interesses "aventureiros" e pessoalíssimos de maiorias momentâneas, dado que não é tão difícil reforma a Constituição, uma vez que a mesma já acumula, na data de hoje, noventa e nove emendas ${ }^{54}$.

Suponhamos, por um momento, então, que aceitássemos o controle de constitucionalidade de emendas à Constituição pela entrega que tal empreitada traria de benefícios compensatórios à limitação da democracia representativa como, por exemplo, a proteção de direitos fundamentais e outros valores indispensáveis para a democracia, como o voto direito, secreto, universal e periódico, a separação dos poderes, a busca pela erradicação da marginalização e da pobreza e redução das mais variadas desigualdades que mazelam essa sofrida república ao sul do mundo -, ainda surgiria um questionamento de teoria constitucional e do estado. Ora, se a dificuldade em reforma a constituição for imensamente grande e fiscalizada pelo Poder Judiciário, tal opção não irá incentivar uma ruptura institucional drástica?

Schier, acredita que não, e argumenta que as ameaças às cláusulas pétreas, na prática, não se trataram de reinvindicações sinceras de uma geração ansiosa por mudanças e sim de interesses corporativistas e elitistas, cuja ambição sofria restrições pela gloriosa proteção de direitos. À propósito, cito:

O risco de ruptura constitucional eventualmente imposta pela existência das cláusulas pétreas, também parece afastada no caso do Brasil. E isto se confirma pois não foram poucos os momentos de crise política, econômica e social que a sociedade brasileira atravessou nesses últimos vinte anos, tendo os direitos fundamentais, protegidos com o grau de intangibilidade, se prestado mais para criar um ambiente de estabilidade do que de instabilidade. Esta autovinculação às cláusulas pétreas aponta que na experiência brasileira a tutela formal máxima dos direitos fundamentais encontra

54 BRANDÃO, Rodrigo. Direitos fundamentais, cláusulas pétreas e democracia. p. 174 - 175. 
RADAELLI, Samuel Mânica; MEDINA, Júlio Eduardo Damasceno. O controle judicial de constitucionalidade de emendas à Constituição. Revista Eletrônica Direito e Política, Programa de Pós-Graduação Stricto Sensu em Ciência Jurídica da UNIVALI, Itajaí, v.15, n.3, 30 quadrimestre de 2020. Disponível em: www.univali.br/direitoepolitica - ISSN 1980-7791

uma ampla legitimidade, não justificando a oposição da 'tese das gerações ${ }^{\prime 55}$.

Tais proposições logram um êxito justificativo imenso, principalmente diante da crise de representatividade que afeta as instituições representativas. Ademais, a princípio, a defesa do controle de constitucionalidade de emendas à Constituição acredita balancear estabilidade institucional e atualização da Constituição, ao passo em que permite a reforma da Constituição por emendas, desde que seja mantido o núcleo essencial do constitucionalismo daquela matriz nacional, e, caso seja atentado contra o mesmo, o Judiciário deve atuar como guardião.

Considerando a realidade brasileira acredita-se que erros e acertos não são monopólios de determinadas instituições ou Poderes da República, isto é, ninguém está tão ao céu e ninguém e ninguém está tão ao mar. Não se confia, contemporaneamente, em terrae brasilis, que os ministros do Supremo Tribunal Federal atuem como Hércules, tampouco que o Congresso Nacional carregue fielmente a representação da vontade soberana do povo.

Diante disso, afirma-se que o controle de constitucionalidade de Emendas à Constituição não é um instituto descartável, apesar de não ser um elemento natural da democracia, ao passo em que materializa um limite, mesmo que jurídico ou constitucional, ao autogoverno coletivo. Conforme foi analisado no tópico anterior, por vezes as decisões do STF foram acertadas, como no caso da ADI n. 1.946, por meio da garantia de um direito social que foi elevado ao status de cláusula pétrea, acertadamente.

Com isso, se quer dizer que é natural, na Separação de Poderes, que os vetos sejam estabelecidos e é legitimo que venha pelo Poder Judiciário. A crítica democrática não pode supor um arranjo institucional onde o Legislativo e o Executivo estejam "intocáveis", até porque, o Judiciário e, em especial o Supremo Tribunal Federal brasileiro, não estão afastados da política, muito pelo contrário, está inserido desde o momento de acessibilidade ao cargo de Ministros, pois passa pela indicação pelo Presidente da República e pela sabatina

${ }^{55}$ SCHIER, Paulo Ricardo. Direitos fundamentais, cláusulas pétreas e democracia: campo de tensão. p. 7. 
RADAELLI, Samuel Mânica; MEDINA, Júlio Eduardo Damasceno. O controle judicial de constitucionalidade de emendas à Constituição. Revista Eletrônica Direito e Política, Programa de Pós-Graduação Stricto Sensu em Ciência Jurídica da UNIVALI, Itajaí, v.15, n.3, 30 quadrimestre de 2020. Disponível em: www.univali.br/direitoepolitica - ISSN 1980-7791

no Senado Federal, até o momento final, da decisão, onde a corte adentra totalmente em decisões de moralidade política.

Conforme aprendemos no Federalista n. 51, não é somente a prestação de contas ao povo que garante um governo regulado, ao revés, essa prática se demonstra insuficiente e carente de um arranjo institucional onde a oposição de interesses este também no espaço público, pela capacidade de autorregulação entre os poderes ${ }^{56}$.

Com tudo isso, busca-se uma interpretação democrática da Constituição, a qual não será buscada sem o Poder Judiciário - e menos ainda se este agir como intérprete supremo ou portador da "última palavra". Note-se, que a crítica, o diálogo e a democracia constroem-se pela inclusão o que denota em não deixar o Poder Judiciário de fora do processo de reforma da Constituição.

Contudo, não quer este trabalho afirmar uma competência absolutista do Poder Judiciário, uma vez que o mesmo deve atuar no controle de constitucionalidade de emendas constitucionais de maneira moderada, se autorregulando, de forma mais incisiva do que quando faz a revisão judicial da legislação ordinária.

Rodrigo Brandão, em sede conclusiva, teoriza nesse sentido:

No controle de constitucionalidade de emendas constitucionais restritivas de direitos fundamentais, 0 Judiciário deve adotar uma postura de mais intensa autocontenção do que quando a restrição provier de lei, na medida em que a sua postura de auto-restrição deve ser diretamente proporcional à solidez e à qualidade deliberativa do consenso obtido no seio do Congresso Nacional.

Igualmente, deve o STF apresentar uma justificativa argumentativa mais sólida ao declarar a inconstitucionalidade de emenda constitucional e ater-se ao projeto de constitucionalismo da Carta da República em detrimento de projetos de nação construídos pelo pensamento dos juristas e filósofos que lá ocupam cadeiras. Não obstante, não podem repetir atuações corporativistas como no caso da ADI

${ }^{56}$ HAMILTON, Alexander; MADISON, James; JAY, John. O Federalista. Tradução: Hiltomar Martins Oliveira. Belo Horizonte: Editora Líder, 2003. p. 317 e 318. 
RADAELLI, Samuel Mânica; MEDINA, Júlio Eduardo Damasceno. O controle judicial de constitucionalidade de emendas à Constituição. Revista Eletrônica Direito e Política, Programa de Pós-Graduação Stricto Sensu em Ciência Jurídica da UNIVALI, Itajaí, v.15, n.3, 30 quadrimestre de 2020. Disponível em: www.univali.br/direitoepolitica - ISSN 1980-7791

n. 3.685, onde, conforme foi observado linhas acima, anulou-se aquilo que se seletivamente uma emenda constitucional. E "poder não querer".

Outro ponto a ser observado é que aceitar o controle judicial de constitucionalidade de emendas constitucionais, para este trabalho, não significa considerar o Poder Judiciário como Poder Moderador ou como intérprete supremo das normas constitucionais, mas somente como mais uma interpretação da Constituição, como uma instância de veto ao poder de reforma, como mais um ator no diálogo institucional, incumbido de uma árdua tarefa hermenêutica para justificar sua decisão que poderá anular a vontade "super-majoritária".

Outro ponto que, para que possamos ser críticos, não pode passar despercebido, diz respeito à constatação de que não é tão simples afirmar que a vontade do tão glorifica Poder Constituinte originário não foi incisiva em permitir tal controle de constitucionalidade de emendas à constituição. Uma leitura democrática do artigo 12, I, "a", da CF/88, não deixa claro que com a expressão "atos normativos" o Constituinte quis incluir as Emendas à Constituição. À propósito, parece que a ordem constitucional vigente não atribuiu tal competência tão naturalmente como faz crer a analisar jurisprudência cristalizada do STF.

Por outro lado, pode se argumentar que a vontade do constituinte objetivou livrar às Emendas à Constituição de revogação, uma vez que optou em retirar do Poder Executivo a incumbência de vetar, diferentemente do que faz no processo legislativo ordinário ou complementar. Quiçá o constituinte pensou o mesmo para o Poder Judiciário, pois não seria interessante (ou inteligente) deixar a competência para tal atribuição de maneira a ser subentendida, pelo uso de termos vagos e imprecisos.

\section{REFERÊNCIAS DAS FONTES CITADAS}

BARROSO, Luís Roberto. Curso de direito constitucional contemporâneo: os conceitos fundamentais e a construção do novo modelo. $4^{a}$ ed. São Paulo: Editora Saraiva, 2013.

BRANDÃO, Rodrigo. Direitos fundamentais, cláusulas pétreas e democracia. Rio de Janeiro: Renovar, 2008. 
RADAELLI, Samuel Mânica; MEDINA, Júlio Eduardo Damasceno. O controle judicial de constitucionalidade de emendas à Constituição. Revista Eletrônica Direito e Política, Programa de Pós-Graduação Stricto Sensu em Ciência Jurídica da UNIVALI, Itajaí, v.15, n.3, 30 quadrimestre de 2020. Disponível em: www.univali.br/direitoepolitica - ISSN 1980-7791

CANOTILHO, José Joaquim Gomes. Direito constitucional e teoria da constituição. 7a ed. Lisboa: Almedina, 2003.

DWORKIN, Ronald. Levando os Direitos a Sério. Tradução: Nelson Boeira. 3a. ed. São Paulo: Editora WMF Martins Fontes, 2010.

FERNANDES, Bernardo Gonçalves. Curso de Direito Constitucional. $7^{a}$ ed. Salvador: Editora Juspodivm, 2015.

HAMILTON, Alexander; MADISON, James; JAY, John. O Federalista. Tradução: Hiltomar Martins Oliveira. Belo Horizonte: Editora Líder, 2003.

SARLET, Ingo Wolfgang; MARINONI, Luiz Guilherme; MITIDIERO, Daniel. Curso de Direito Constitucional. 6a ed. São Paulo: Saraiva, 2017.

SCHIER, Paulo Ricardo. Direitos fundamentais, cláusulas pétreas e democracia: campo de tensão. Revista Direitos Fundamentais e Democracia, v. 6, 2009.

SIEYÈS, Emmanuel Joseph. A constituinte burguesa: o que é o terceiro estado?. Rio de Janeiro: Líber Juris, 1988.

SOUZA NETO, Cláudio Pereira de; SARMENTO, Daniel. Direito Constitucional Teoria, história e métodos de trabalho. $2^{a}$ ed. Belo Horizonte: Fórum, 2014.

SOUZA NETO, Cláudio Pereira. Verticalização, cláusula de barreira e pluralismo político: uma crítica consequencialista à decisão do STF na ADIn n. 3685-8. Disponível em: https://bdjur.stj.jus.br/jspui/handle/2011/30652. Acesso em: 02 jun. 2018, às 00h31min.

VEGA, PEDRO. La Reforma Constitucional y La Problematica del Poder Constituyente. $5^{a}$ reimpresión. Madrid: Tecnos, 2000.

VIEIRA, Oscar Vilhena. Supremocracia. In: Revista Direito FGV. v. 04, N. ${ }^{\circ} 02$. São Paulo: Fundação Getúlio Vargas, 2008. 